\title{
Okul Yöneticilerinin Öğretmenleri Etkilemede Kullandıkları Yönetsel Etki Taktikleri*
}

\author{
Administrative Impact Tactics Used By School Administrators to \\ Influence Teachers*
}

Aynur B.BOSTANCI ${ }^{1}$, Gökhan DEMIRHAN² ${ }^{2}$ Sebila BÜLBÜL ${ }^{3}$

- Geliş Tarihi: 25.05.2019• Kabul Tarihi: 22.07.2019• Yayın Tarihi: 22.07.2019

\begin{abstract}
$\ddot{O} \mathbf{z}$
$\mathrm{Bu}$ araştırma okul yöneticilerinin öğretmenlere karşı kullandıkları etki taktiklerinin, öğretmen ve yönetici görüşlerine göre ortaya konulmasını amaçlamıştır. Araştırmada nitel araştırma yöntemi kullanılmıştır. Araştırmanın çalışma grubunu, Uşak ilinde görev yapan 18 öğretmen ile 10 okul yöneticisi oluşturmaktadır. Araştırmanın sonuçlarına göre, öğretmenlerin çoğu, okulla bütünleşmelerini sağlamak için okul yöneticilerinin kendilerini okulun bir parçası gibi hissettirdiklerini, kararlara kattıklarını, değer verdiklerini ve yasal güçlerini kullandıklarını; okul yöneticileri ise, aile ortamı oluşturma ve iletişim kurma taktiklerini kullandıklarını belirtmişlerdir. Yine öğretmenlerin çoğu, iş başarılarının artırılmasına yönelik okul yöneticilerinin, yasal güç kullanma ve motive etme taktiklerini kullandıklarını belirtirlerken; okul yöneticileri kullandıkları etki taktiklerini motive etme, mesleki gelişim için yönlendirme ve görev dağılımını uygun yapma şeklinde sıralamaktadırlar. Araştırmanın diğer bir sonucu da, öğretmenlerin çoğunun görevlerini yerini getirmeleri için okul yöneticilerinin yasal güç kullandıklarını dile getirmesi iken; yöneticilerin sonuçlara vurgu yapma, mesleğin önemini vurgulama ve başarı için ortam oluşturma gibi taktikleri uyguladıklarını belirtmeleridir. Hem öğretmenlere hem de okul yöneticilerin çoğuna göre ööğretmenlerin mesleki gelişimlerinin sağlanmasına yönelik okul yöneticilerin kullandıkları etkileme taktikleri, hizmet içi eğitime yönlendirme ve mesleki gelişimi sağlamadır. Öğretmenlerin çoğu, okulun geliştirilmesine yönelik çaba göstermeleri için okul yöneticilerinin takdir etme ve yasal güç kullandıklarını düşünürlerken; yöneticiler, takdir ederek, okulu benimseterek ve kişisel özelliklerine göre etkileyerek öğretmenleri etkilediklerini dile getirmektedirler.
\end{abstract}

Anahtar sözcükler: etki taktikleri, etkileme taktikleri, okul yöneticisi

Atıf:

Bostanc1, A. B, Demirhan, G. ve Bülbül, S. (2019). Okul yöneticilerinin öğretmenleri etkilemede kullandıkları yönetsel etki taktikleri. Pamukkale Üniversitesi Eğitim Fakültesi Dergisi, 47, 422438.doi:10.9779/pauefd.569993

\footnotetext{
* Bu makale EYFOR-8/2017 Uluslararası Eğitim Yönetimi Forumu'nda sözlü bildiri olarak sunulmuş çalışmanın geliştirilmiş halidir.

${ }^{1}$ Doç. Dr., Uşak Üni. Eğitim Fakültesi, aynur.bozkurt @usak.edu.tr https://orcid.org/0000-0002-7927-6063

${ }^{2}$ Dr. Öğt. Üyesi, Uşak Üni. Eğitim Fakültesi, gokhan.demirhan@usak.edu.tr https://orcid.org/0000-0003-4428-0502

${ }^{3}$ Öğretmen, Uşak Milli Eğitim Müdürlüğü, bulbulsebila@hotmail.com https://orcid.org/0000-0002-7075-4591
} 


\title{
Okul Yöneticilerinin Öğretmenleri Etkilemede Kullandıkları Yönetsel Etki Taktikleri
}

\begin{abstract}
This study aims to reveal the tactics of school administrators against teachers according to teachers 'and administrator' views. Qualitative research method has been used in the research. The study group consists of 18 teachers and 10 school administrators working in Uşak. According to the results of the research, most of the teachers stated that school administrators made them feel the part of the school ,participated them to the decisions, added value, and used their legal powers to ensure their integration with the school; school administrators stated that they used the tactics of creating a family environment and communication. While most of the teachers stated that school administrators use tactics of using legal power and motivation to increase their success; school administrators use motivation to influence their tactics, directing them for professional development and making the appropriate task distribution. Another result of the research is that the teachers say school administrators use legal power in order for the teachers to fulfill their duties while school administrators indicate that they emphasize the results, emphasize the importance of the profession and create an environment for success. Influence tactics used by most teachers and school administrators to provide professional development of teachers provide orientation and in-service training. In order for teachers to make efforts to improve the school, most of the teachers think that school administrators use appreciation and legal power, whereas the administrators say they influence the teachers by encouraging and by adopting to the school and influencing according to personal characteristics.
\end{abstract}

Keywords: impact tactics, influence tactics, school administrator.

Cited:

Bostanc1, A. B, Demirhan, G. \& Bülbül, S. (2019). Administrative impact tactics used by school administrators to influence teachers. Pamukkale Üniversitesi Ĕ̈itim Fakültesi Dergisi, 47, 422-438. doi:10.9779/pauefd.569993 


\section{Giriş}

Örgütsel amaçların gerçekleşmesinde en önemli öğe örgüt çalışanlarıdır. Bu nedenle örgüt çalışanlarının, örgüt amaçları doğrultusunda rollerini yerine getirmeleri için etkilenmeleri kritik bir öneme sahiptir (Kipnis, Schmidts, Swaffin-Smith\& Wilkinson,1984; Balser \& Carmin, 2009; Mosca, Fazzari \& Buzza, 2010; Lee, Chiang, Chen \& Chen, 2010). Okulun başarısı için de okul yöneticileri, öğretmenleri güdülemede, örgütsel amaçlar etrafında birleştirmede, amaç doğrultusunda öğretmenlerin tutum ve davranışlarını değiştirmede, kendilerini okula adamalarını sağlamada ve en önemlisi de eğitim-öğretim sürecini geliştirmede etkileme taktiklerini kullanabilmelidirler (Akçay, 2003; Duyar, Aydın \& Pehlivan, 2009). Çünkü yöneticilerin örgüt üyelerini etkileme derecesi, okulun amaçlarına ulaşmasını etkileyen değişkenlerden biridir. Öğretmenler, okul etkililiği ve başarısında kilit bir rol üstlenmektedirler (Doğan \& Çelik, 2019) Öğretmenin profesyonel gelişimi ve başarısı okul yöneticilerinin rol ve sorumluluklarından birisidir ve okulda kalite güvencesi mekanizması olarak görülmektedir. Bu nedenle öğretmenin başarısı, okul yöneticisi tarafından etkilenerek artırılmaya çalışılmalıdır (Maharaj, 2014; Kraft \& Gilmour, 2016). Yönetsel olarak etkileme, örgüt üyelerinin davranışlarını yönlendirerek örgütsel amaçlara ulaşmalarının sağlanması olarak tanımlanabilmektedir (Balcı \& Aydın, 2003). Yöneticilerin astlarının davranışlarını doğrudan etkili bir biçimde yönetmelerinin yolu ise, etki taktikleridir. Yöneticiler bu yolla çalışanlarını güdeleyerek, ihtiyaç duyulan davranışı göstermelerini saylayabileceklerdir (Kacmar, Carlson \& Harris, 2013).

Yöneticiler örgütlerini sorunsuz çalıştırmak, örgütsel ve kişisel hedeflerine ulaşmak, örgütsel değişimi başlatmak için astlarının tutum ve davranışlarını değiştirebilmelidirler (Jiasheng, 2011). Bu anlamda örgütte arzu edilen sonuçlara ulaşılması için etki taktiklerini kullanarak, çalışanların örgütün hedeflerine doğru ilerlemesini sağlamak, değişime karşı direnci azaltmak, yoğun işler için gösterilen çabayı sürekli kılmak, çalışanların bireysel hedeflerini desteklemek ve ast üst ilişkilerini geliştirmek gibi stratejileri uygulayabilmelidirler. Yöneticiler, çalışanları rehber, iş arkadaşı ya da koç olarak etkileyebilmeli ve etkileme taktikleri konusunda kendini geliştirmelidirler (Baldwin \& Grayson, 2004). Kipnis ve diğerleri(1984) yöneticilerin çalışanlarını etkilemek için en uygun stratejiyi seçmelerinin eğitim yoluyla geliştirilebileceğini belirtmektedirler. Yönetimsel etkileme, çalışanlarda davranış ve tutum değişimi yanında, örgütte fikir birliğinin yaratılması, daha verimli, yaratıcı, paylaşılan hedefe odaklanmıs bir ortam yaratılması gibi amaçlara da hizmet etmektedir (Baldwin \& Grayson, 2004; İspir, 2008). Başarılı bir yönetici çalışanları talimatlarla yönlendirerek, beklentilerini açıklığa kavuşturarak, çalışanların gelişimi için kaynak ve destek sağlayarak, çalışanı işini yapmaya güdeleyerek ve çalışanın çabasını takdir ederek çalışanın iş başarısını en üst düzeye çıkarabilmektedir. Çalışanın ilerlemesi desteklendiği zaman motivasyonu ve örgüte bağlılığı daha da artmaktadır (Barutçugil, 2002). Kipnis ve Schmid'e (1988) göre etki taktikleri, çalışanların bireysel iş çıktıları üzerinde etkilidir. Bu çıktılar örgütleri başarı ve başarısızlığa sürükleyebilmektedir.

Okul yöneticilerinin etkileme becerisine güç kazandıran kaynakları, bilgi ve becerilerinin sağladığ1 teknik gücü, sağlıklı ilişkilerinin sağladığı insan ilişkileri gücü, eğitim, bilgi ve becerilerinin sağladığı eğitimcilik gücü ve okul değer sistemlerinin sağladığ 1 sembolik ve kültürel gücüdür (Erdoğan, 2000, Akt. Aydoğan, 2008). Okul yöneticileri, bu güçlerini kullanarak öğretmenleri etkileyebilmelidir. Bursalığlu'na (2002) göre etkilemenin iç ve diş yolları bulunmaktadır. Etkinin dış yolları yetki, enformasyon ve hizmet içi eğitim; iç etki yolları ise, bireysel gereksinmelerin karşılanması, karar sürecine katılma olanağı ve örgütün üyelere benimsetilmesidir. Hoy ve Miskel (2010) etkili yöneticilerin formel otoritesi yeterli olmadığında, çalışanlarıyla gücü paylaşmalarını ve onları güçlendirerek uzmanlık sisteminden faydalanmalarını önermektedirler. 


\section{Okul Yöneticilerinin Öğretmenleri Etkilemede Kullandıkları Yönetsel Etki Taktikleri}

Yönetsel etkide, dört öğenin ağırlıkla vurgulandığı görülmektedir. Bunlar; gerçekleştirilecek olan amaç, bu amacı gerçekleştirmekle görevli yönetici, amac1 gerçekleştirmeye katkıda bulunacak olan çalışanlar ve etkilemeye yol açan yöntemler olarak sıralanabilmektedir. Bu doğrultuda etki; amaç, yönetici, yönetilen ve yöntemden meydana gelen bir sistemdir. Yönetici etkinin bütün ögeleri arasında koordinatör rolünü oynamaktadır (Sarıtaş, 1991, Akt: Kabaklı Çimen \& Gezer, 2016). Bunların yanında Yukl ve arkadaşları $(1992 ; 1996)$ çalışanları etkilemek için örgütlerde oluşan etki taktiklerinin en kapsamlı sınıflandırmasını yapmışlardır. Bu taktikler rasyonel ikna, ilham vericilik, danışma, kendini beğendirmek, değişim, kişisel çekicilik, koalisyon, yasal dayanak sunmak ve baskı olmak üzere dokuz şekilde görülmektedir (Akt. Cable \& Judge, 2003; Eroğlu \& İspir, 2006; Yulk, 2013). Kipnis ve diğerleri de (1984) etki taktiklerini, neden gösterme, samimiyet, koalisyon, pazarlık, diretme, üstün desteğini alma ve yaptırım uygulama olarak belirtmişlerdir. Akçay'a göre (2003) ise, alan yazında değişik etki taktiklerine de rastlanabilmektedir. Bu etki taktikleri şu şeklidedir: Schein (1978) 'e göre etkileme yolları, çalışanların gereksinmelerini dikkate alma, onların kabul edilme, ait olma ve kimlik duyguları ile ilgilenme, çalışanlarla üst makamlar arasında aracılık yapma, çalışanların ihtiyaç ve duygularını dinleyip anlamaya çalışma, onlara anlayış göstermedir. Miles (1980) bürokratik engeller yaratma, kendisini ve etkinliklerini kabul ettirme, astlar arasında rekabet yaratma, belirsizlik yaratma, belirli kişi ve bilgilere ulaşmayı engelleme, örgüt kaynaklarını kontrol etme, örgüt içi muhalefeti etkisiz kılma, güçlü kişilik örneği sergileme olarak etki taktiklerini sıralamaktadır. Yine Erçetin (1993) makam, kişilik, ilgi, uzmanlık, ödül, ceza, güçsüzlük; Aydın (1994) ise, çalışanı yetiştirme, bilgilendirme, destekleme, öğüt verme, katılmayı sağlama, ödüllendirme, emir verme ve plânlama olarak etkileme taktiklerini açıklamışlardır (Akt. Akçay, 2003). Yukl (2013) çalışanları etkilemenin örgütte bağlılığını artırdığını özellikle akıl yoluyla ikna etme, istişarede bulunma, teşvik edici talepte bulunma gibi etkileme davranışlarında bulunmalarının çalışanlarda bağlılık oluşturacağını ileri sürmektedir. Koşar ve Çalık da (2011) okul yöneticisinin etkileme davranışlarının, öğretmenlerin tutum ve davranışları üzerinde etkileri olduğunu ve okul kültürünü etkilediğini belirtmektedirler. Yine örgütsel etkileme taktikleri öğretmenlerin iş performansını etkilediği araştırmalarla ortaya konulmuştur (Higgins, Judege \& Ferris, 2003; Jiasheng, 2011). Eğitim sisteminin verimliliği okul yönetiminin amaçlarını gerçekleştirmesine bağlıdır. Okulun amaçlarını gerçekleştirmesi ise büyük ölçüde okul yöneticisinin öğretmenleri etkileyebilmesine bağlıdır (Kabaklı Çimen \&Gezer, 2016).

Şimdiye kadar yapılan açıklamalardan öğretmenlerin okulun ve kendilerinin amaçlarına ulaşmalarında, okul yöneticileri tarafından etkilemelerinin oldukça önemli olduğu anlaşılmaktadır. Alan yazında okul müdürlerinin öğretmenleri etkiledikleri taktiklerin belirlenmesine yönelik Uygun (2006), Duyar, Aydın ve Pehlivan (2009), Aydın ve Pehlivan (2010), Koşar ve Çalık (2011), Mangaltepe (2012), Gözü (2012), Kuru Çetin ve Çınkır (2014), Çetin ve Çınkır (2015), Dağlı ve Çalık (2016), Kabaklı Çimen ve Gezer (2016) Çetin, Ünal ve Özaslan (2017), Çetin ve Çınkır (2018) ve Bülbül (2019) tarafından yapılan bazı araştırmalara rastlamak mümkündür. Ancak belirtilen araştırmaların genellikle nicel araştırmalar olarak önceden belirlenen etki taktiklerini okul yöneticilerinin ne düzeyde kullandığını belirlemeye yönelik olduğu görülmektedir. Bu çalışmada ise, alan yazında bilinen etki taktikleri dışında okul yöneticilerinin ögretmenleri etkilemede kullandıkları etki taktikleri belirlenmeye çalışılmıştır. $\mathrm{Bu}$ nedenle bu araştırmayla, okul yöneticilerinin okullarda hangi etki taktiklerini kullandıkları öğretmen ve yönetici görüşlerine göre değerlendirilerek ortaya konulmaya çalışılmıştır. Bu amaçla araştırmada aşağıdaki sorulara cevap aranmıştır.

1 Öğretmen görüşlerine göre, öğretmenlerin okulla bütünleşmelerine, iş başarılarına, aldıkları görevleri yerine getirmelerine, mesleki gelişimlerine ve okulun gelişimi için çaba göstermelerine yönelik okul yöneticilerinin kullandıkları etkileme taktikleri nelerdir? 
2. Yönetici görüşlerine göre, öğretmenlerin okulla bütünleşmelerine, iş başarılarına, aldıkları görevleri yerine getirmelerine, mesleki gelişimlerine ve okulun gelişimi için çaba göstermelerine yönelik okul yöneticilerinin kullandıkları etkileme taktikleri nelerdir?

\section{Yöntem}

\section{Araştırma deseni}

Araştırmada nitel araştırma yöntemi kullanılmıştır. Araştırmada olgu bilim deseniyle okul yöneticilerinin kullandıkları etkileme taktikleri öğretmen görüşlerine göre belirlenmeye çalışılmıştır. Çünkü olgu bilim, farkında olduğumuz ve bize tanıdık gelen, ancak derinlemesine ve ayrıntılı bir şekilde bilmediğimiz olgulara odaklanarak bu olguları araştırmayı amaçlayan bir araştırma desenidir (Yıldırım \& Şimşek, 2005).

\section{Araştırmanın çalışma grubu}

Araştırmanın çalışma grubu belirlenirken gönüllülük esas alınmıştır. Araştırmanın çalışma grubunu, Uşak ilinde görev yapan 18 öğretmen ile 10 okul yöneticisi oluşturmaktadır. Araştırmanın çalışma grubuna ilişkin bilgiler aşağıdaki şekildedir.

Tablo 1. Çalışma Grubuna İlişkin Demografik Bilgiler

\begin{tabular}{lcc}
\hline Değişken & Görev & Sayı \\
\hline Görev & Yönetici & 10 \\
Meslek Kıdemi & Öğretmen & 18 \\
& Yönetici & $7-21$ yıl arası \\
Cinsiyet & Öğretmen & $2-20$ yıl arası \\
& Yönetici & 1 kadın, 9 erkek \\
\cline { 2 - 3 } & Öğrtemen & 10 Kadın, 8 erkek \\
\hline
\end{tabular}

\section{Verilerin toplanması}

Araştırmada veriler yarı yapılandırılmış görüşme tekniği ile toplanmıştır. Yarı yapılandırılmış görüşme formu hazırlanırken konu ile ilgili alan yazın taranmış, öğretmen ve yöneticilerle ön görüşmeler yapılmış ve alan uzmanlarının görüşleri alınmıştır. Daha sonra verilerin toplanması için son hali oluşturulan yarı yapılandırılmış görüşme formu ile öğretmen ve yöneticilerle görüşülmüştür. Veriler ses kaydı yöntemiyle toplanmıştır. Böylece, veri kaybı olması engellenmiştir. Veriler doyum noktasına ulaştığında veri toplama sonlandırılmıştır.

\section{Verilerin analizi}

Verilerin analizinde içerik analizi tekniğinden yararlanılmıştır. İçerik analizinde temelde yapılan işlem, birbirine benzeyen verileri belirli kavramlar ve temalar çerçevesinde bir araya getirmek ve bunları okuyucunun anlayabileceği biçimde düzenleyerek yorumlamaktır. İçerik analizi belli kurallara dayalı kodlamalarla bir metnin bazı sözcüklerinin daha küçük içerik kategorileriyle özetlendiği sistematik, yenilenebilir bir teknik olarak tanımlanmaktadır (Yıldırım \& Simsek, 2005; Büyüköztürk, Çakmak, Akgün, Karadeniz \& Demiral, 2012). Verilerin analizi için öncelikle çalışma grubuyla yapılan görüşmeler, öğretmen ve yönetici kodları ve bu kodlar altındaki tema adlarından oluşan kodlar altında bilgisayar ortamına aktarılmıştır. Daha sonra en çok geçen sözcüklere odaklanılarak alt temalar oluşturulmuştur. Verilerin çözümlenmesinden sonra, veriler tekrar başka bir alan uzmanına verilmiş ve temalar ve alt temalar çıkarması istenmiştir. Çıkarılan temalar arasında tutarlılıklar olduğu belirlenmiştir. Miles ve Huberman (1994) formülüne göre [(P= görüş birliği /görüş birliği + görüş ayrılığ1)x100] \%91'lik bir görüş birliği oranı elde edilmiştir. Temaya yönelik bulguların ortaya konulmasında, yapılan 
görüşmelerden birebir aktarmalar verilmiştir. $\mathrm{Bu}$ aktarmalarda ve verilerin analizinde öğretmenler için Ö1-Ö18 yöneticiler için Y1-Y10 arasında kodları kullanılmıştır.

\section{Bulgular}

$\mathrm{Bu}$ bölümde öğretmen ve yönetici görüşlerine göre okul yöneticilerinin okullarda öğretmenleri etkilemede kullandıkları etki taktiklerine ilişkin bulgular, beş tema başlığı altında toplanan alt temalarla verilmiştir Aşağıdaki Tablo 2'de araştırma bulgularının toplandığı temalar yer almaktadir.

Tablo 2. Okul Yöneticilerinin Öğretmenleri Etkileme Taktiklerini Kullandıkları Alanlara Yönelik Oluşan Temalar

TEMA 1 : Okulla bütünleşme

TEMA 2 : İş başarısının artırılması

TEMA 3 : Görevlerin yerine getirilmesi

TEMA 4 : Mesleki gelişimin sağlanması

TEMA 5 : Okulun geliştirilmesine yönelik çaba gösterilmesi

Tablo 2 de görüldüğü gibi, araştırma bulguları beş tema altında toplanmaktadır. $\mathrm{Bu}$ temalar, ögretmenlerin okulla bütünleşmelerine, iş başarılarının artırılmasına, görevlerini yerine getirmelerinin sağlanmasına, mesleki gelişimlerinin sağlanmasına ve okulun geliştirilmesine yönelik çaba gösterilmelerinin sağlanmasına yöneliktir. Aşağıdaki Tablo 3 'te öğretmenlerin okulla bütünleşmesinin sağlanmasına yönelik tema ve alt temalara ilişkin bilgiler yer almaktadir.

Tablo 3. Öğretmenlerin Okulla Bütünleşmesinin Sağlanmasına Yönelik Tema ve Alt Temalar

TEMA 1 : Okulla bütünleşme

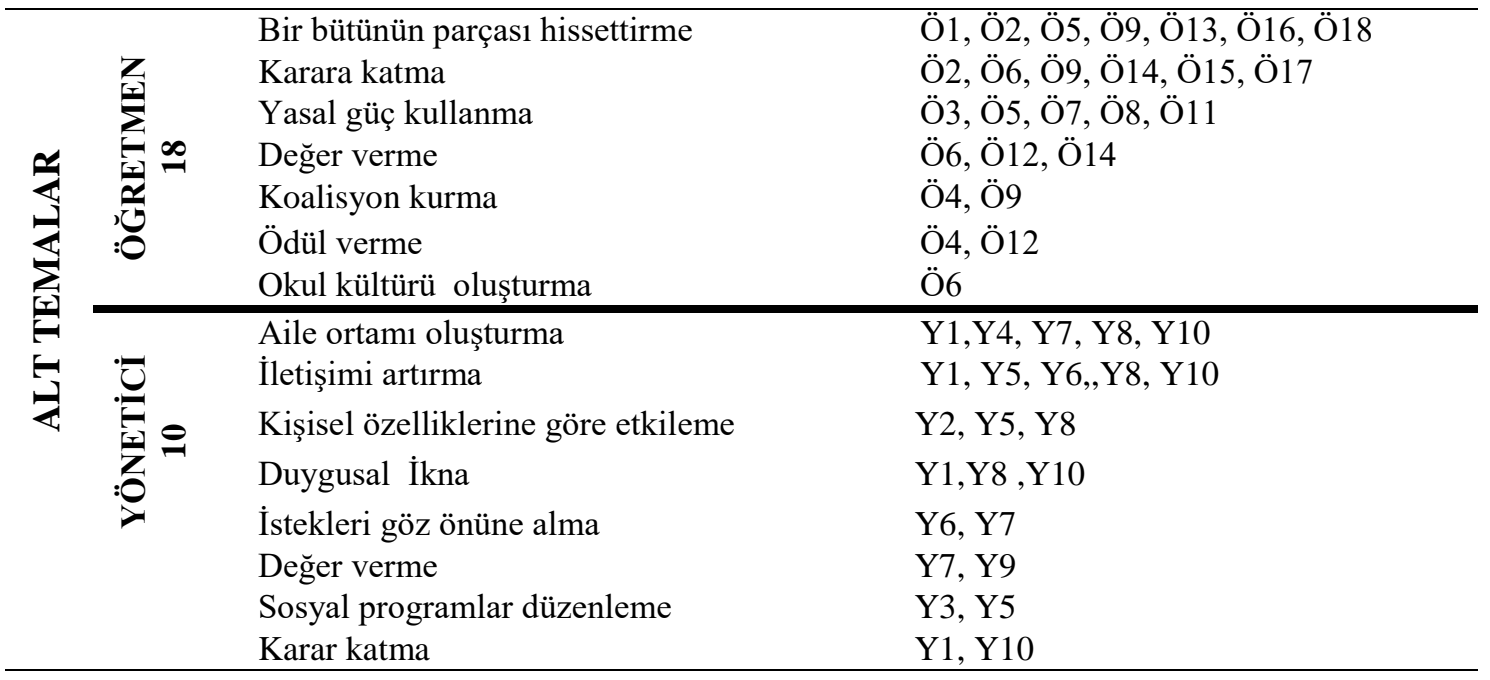

Yukarıdaki Tablo 3 'ten anlaşılacağı üzere, "okulla bütünleştirme" temasına yönelik olarak, ögretmenlerin çoğu okul yöneticilerinin kendilerinin olkulla bütünleşmelerini sağlamak için, bir bütünün parçası hissettirme, karara katma ve yasal gücünü kullanma gibi etki taktiklerini kulandıklarını belirtmektedir. Bazı ögretmenlerde okul yöneticilerinin kendilerine değer vererek, onlarla koalisyon kurarak, ödül vererek ve bütünleşmeye yönelik okul kültürü 
oluşturarak kendilerini etkilediklerini ifade etmektedirler. Okul yöneticileri ise, öğretmenleri okul ile bütünleştirmede yasal güç kullandıklarından hiç bahsetmemekte, en çok okulda aile ortamı oluşturma, iletişimi artırma gibi etki tatktiklerini kullandıklarını dile getirmektedirler. Yine bazı okul yöneticileri bu konuda, öğretmenlerin kişisel özelliklerini göz önünde bulundurduklarını, duygusal iknaya başvurduklarını ve öğretmenlerin istekleri göz önüne alarak değer verdiklerini, sosyal programlar düzenlediklerini ve karara kattıklarını ifade etmişlerdir.

Öğretmenlerin okulla bütünleşmelerini sağlaması konusunda, okul yöneticilerinin kullandığ1 etki taktiklerine yönelik bir öğretmen "Okul yöneticim okulla bütünleşmemizi sağlamak için öğretmenleriyle koalisyon içinde olur. Görev dağılımı yaparken ya da herhangi bir etkinlik için fikrimizi alır. Bizi de işin içine katar. Böylelikle kendimizi bir bütünün parçası gibi hissederiz" (Ö9) diyerek görüşlerini dile getirmiştir.

Yine bir okul yöneticisi bu konuda kısaca "Öğretmenler okulu sadece çalıştıkları yer olarak görmemelidirler. Okul içinde bir aile ortamı oluşturmaya çalışırım.Kendilerini rahat hissetmeleri için elimden geleni yaparım"(Y4) ifadelerini kullanmıştır. Aşağıdaki Tablo 4'te öğretmenlerin iş başarısının artırılmasına yönelik tema ve alt temalara ilişkin bilgiler verilmiştir.

Tablo 4. Öğretmenlerin İş Başarısının Artırılmasına Yönelik Tema ve Alt Temalar

\begin{tabular}{lll}
\hline & TEMA 2 : İş başarısının artırılması \\
\hline & Yasal güç kullanma & Ö1, Ö4, Ö7, Ö8, Ö11, Ö18 \\
Motive etme & Ö2, Ö6, Ö9, Ö8, Ö14, Ö17 \\
Takdir etme & Ö4, Ö12, Ö13 \\
Örnek olma & Ö2, Ö16 \\
Karara katma & Ö15, Ö16 \\
& Başarı için ortam oluşturma & Ö4, Ö9 \\
Görevlendirme yapma & Ö3 \\
& Motive etme & Y3, Y5, Y8, Y9 \\
& Mesleki gelişim için yönlendirme & Y4, Y5, Y8, Y9 \\
& Görev dağılımını uygun yapma & Y2, Y5 \\
& Başarı için uygun ortam oluşturma & Y6, Y7 \\
& Mesleki değerleri vurgulama & Y7, Y9 \\
& Rekabet ortamı oluşturma & Y9 \\
& Liderlik yapma & Y8 \\
& Karara katma & Y10 \\
\hline
\end{tabular}

Yukarıdaki Tablo 4'te görüleceği gibi, öğretmenlerin çoğu başarılarının artırılmasına yönelik okul yöneticilerinin kendilerini etkilemede, yasal güç ve motive etme taktiklerini kullandıklarını belirtirlerken; okul yöneticilerinin çoğu kullandıkları etkileme taktiklerini motive etme, mesleki gelişim için yönlendirme ve görev dağılımını uygun yapma şeklinde sıralamaktadırlar. Yine ögretmenler, okul yöneticilerinin başarılarını artırmak için takdir etme, örnek olma karara katma başarı için ortam oluşturma ve görevlendirme yapma taktiklerini kullandıklarını dile getirirken; okul yöneticileri, öğretmenlerin başarısını artırmaya yönelik başarı için uygun ortam oluşturma mesleki değerleri vurgulama rekabet ortamı oluşturma liderlik yapma ve karar katma gibi taktikleri kullandıklarını belirtmektedirler. Okul yöneticilerinin öğretmenlerin iş başarısının artırılması için kullandıkları etki taktiği konusunda bir öğretmen görüşü şu şekildedir.

"Kesinlikle yasal güç diyebilirim bu sorunun cevabına. Bizlere karizmatik ya da uzmanlık güçlerini hissettiremeyeceği için yasal gücüne sarılır. Bu da istemediğimiz ve yapmakta zorunlu olmadığımız durumları yapmak zorunda bırakılmamıza sebep olur"(Ö7). 


\section{Okul Yöneticilerinin Öğretmenleri Etkilemede Kullandıkları Yönetsel Etki Taktikleri}

Yine bir yönetici, "Motivasyon bu durum için önemli bir taktiktir. Kişisel başarıları ön plana çıkarıp örnek gösteririm. Gereken hizmet içi eğitimlerin alınması için öğretmenlere rehberlik ve öncülük ederim" (Y8) cümleleriyle görüşünü ifade etmiştir. Aşağıdaki Tablo 5'te ise, öğretmenlerin görevlerini yerine getirmelerini sağlamasına yönelik tema ve tema altında yer alan alt temalara ilişkin bilgiler görülmektedir.

Tablo 5. Öğretmenlerin Görevlerini Yerine Getirmelerinin Sağlanmasına Yönelik Tema ve Alt Temalar

\begin{tabular}{|c|c|c|c|}
\hline & TFMA & evlerin yerine getirilmesinin sağlar & \\
\hline 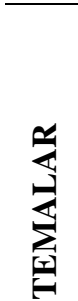 & $\sum_{\substack{0 \\
:}}^{\substack{\mathbf{x} \\
\text { : }}}$ & $\begin{array}{l}\text { Yasal güç kullanma } \\
\text { Destek olma } \\
\text { Güvenini hissettirme } \\
\text { Mesleğin önemini vurgulama } \\
\text { Görevi açılama } \\
\text { Sonuçlara vurgu yapma }\end{array}$ & $\begin{array}{l}\text { Ö2, Ö3, Ö4, Ö5, Ö7, Ö8, } \\
\text { Ö11,Ö14, ,Ö16 } \\
\text { Ö5, Ö9, Ö12, Ö15, Ö18 } \\
\text { Ö1,Ö4,Ö18 } \\
\text { Ö2, Ö6, Ö17 } \\
\text { Ö10, Ö18 } \\
\text { Ö12, Ö18 }\end{array}$ \\
\hline 卢 & 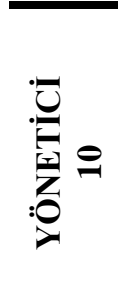 & $\begin{array}{l}\text { Sonuçlara vurgu yapma } \\
\text { Mesleğin önemine vurgu } \\
\text { Mesleki başarıya ortam oluşturma } \\
\text { Ödüllendirme } \\
\text { Yasal gücünü kullanma } \\
\text { Pazarlık yapma } \\
\text { Örnekler gösterme }\end{array}$ & $\begin{array}{l}\mathrm{Y} 1, \mathrm{Y} 2, \mathrm{Y} 3, \mathrm{Y} 5, \mathrm{Y} 10 \\
\mathrm{Y} 2, \mathrm{Y} 5, \mathrm{Y} 7 \\
\mathrm{Y} 1, \mathrm{Y} 2, \mathrm{Y} 9 \\
\mathrm{Y} 7, \mathrm{Y} 8, \mathrm{Y9} \\
\mathrm{Y4}, \mathrm{Y} 6 \\
\mathrm{Y} 8 \\
\mathrm{Y} 10\end{array}$ \\
\hline
\end{tabular}

Tablo 5 incelendiğinde, öğretmenler görevlerini yerini getirmelerini sağlamak için okul yöneticilerinin yasal güç kullanma, destek olma taktiklerini kullandıklarını dile getirilerken; okul yöneticilerin genellikle sonuçlara vurgu yapma, başarı için ortam oluşturma gibi taktikleri uyguladıklarını belirttikleri görülmektedir. Bunun yanında öğretmenleri etkilemede yöneticilerin kutlandıkları sonuçlara vurgu yapma ve mesleğin önemine vurgu yapma konusunda öğretmen ve okul yöneticilerin benzer düşündükleri görülmektedir. Ancak öğretmenlerin çoğu kendilerini etkilemede, yöneticilerin yasal gücü kullandıklarını belirtirlerken, okul yöneticilerinden sadece iki yönetici yasal gücü kullandığını dile getirmiştir. Yine öğretmenler okul yöneticilerinin güven hissettirerek, görevi açıklayarak yöneticilerin kendilerini etkilediklerini dile getirmişlerdir. Yöneticiler ise, ödüllendirme pazarlık yapma ve örnekler gösterme yoluyla öğretmenlerin görevlerini yerine getirmelerini sağladıklarını ifade etmişlerdir.

Okul yöneticilerinin öğretmenlerin görevlerini yerine getirmelerine yönelik etki taktikleri konusunda bir öğretmen "Okul müdürümüz bizlere öncelikle bu görevlerin neden yapılması gerektiğini açıklar ve daha sonra eğer gönüllü olarak olmazsa yasal olarak yaptıracağını vurgular" (Ö7) diyerek görüşünü sunmuştur.

Bir yönetici ise, "Verilen görevlerin öğrencilerimiz üzerindeki katkılarından bahsederim. $\mathrm{Bu}$ iş verimli şekilde yapılırsa hangi sonuçlar ortaya çıkar verimsiz yapılırsa hangi sonuçlar ortaya çıkar bunları istişare ederim" (Y8) demektedir. Tablo 6'da öğretmenlerin mesleki gelişimlerinin sağlanmasına yönelik tema ve tema altında yer alan alt temalara ilişkin bilgiler verilmiştir.

Tablo 6'dan anlaşılacăğ üzere, hem öğretmenler hem de okul yöneticileri öğretmenlerin mesleki gelişimlerine yönelik okul yöneticilerinin kullandıkları etki taktikleri konusunda benzer düşünmektedir. Öğretmenlere ve okul yöneticilerinin çoğu kullanılan etkileme taktiklerinin hizmet içi eğitime yönlendirme ve mesleki gelişimi sağlama ve destekleme olduğundan bahsetmektedirler. Bunun yanında öğretmenler mesleki gelişimlerinin sağlanmasına yönelik olarak okul yöneticilerinin kendilerini, koşulları kolaylaştırma, bilimsel etkinlikleri destekleme kararlara katma ve ödül yoluyla desteklediklerini belirtmektedir. Okul yöneticileri ise, 
öğretmenleri etkilerken mesleki değeri vurgulama sorumluluk aşılama motive etme ve kararlara katma gibi etkileme taktiklerini kullandıklarını belirtmektedirler.

Tablo 6. Öğretmenlerin Mesleki Gelişimlerinin Sağlanması Teması ve Alt Temaları

\begin{tabular}{lll}
\hline TEMA 4 : Mesleki gelişimin sağlanması & \\
\hline & Hizmet içi eğitime yönlendirme & Ö3, Ö4, Ö5, Ö6, Ö12, Ö14, Ö17 \\
& Mesleki gelişimini sağlama & Ö8, Ö9, Ö10, Ö16, Ö18 \\
& Hiç karışmama & Ö2, Ö4, Ö7, Ö11, Ö13 \\
& Koşulları kolaylaştırma & Ö1, Ö6, Ö15 \\
& Bilimsel etkinliklerini destekleme & Ö3, Ö6 \\
& Karara katılma & Ö6,Ö15 \\
& Ödül verme & Ö3 \\
\hline & Mesleki geliş̧imini destekleme & Y1, Y4, Y6, Y7, Y8, Y10 \\
& Hizmet içi eğitime yönlendirme & Y1, Y5, Y6, Y8, Y10 \\
& Mesleki değeri vurgulama & Y2, Y5, Y8 \\
& Takdir etme & Y1,Y8 \\
& Sorumluluk aşıllama & Y1 \\
& Motive etme & Y1 \\
& Karar katma & Y7 \\
\hline
\end{tabular}

Okul yöneticilerinin öğretmenlerin iş başarısının artırılması için kullandıkları etki taktiği konusunda bir öğretmen görüşü şu şekildedir. "Mesleki gelişim için okul yöneticim teşvik edici tutum sergiler. Öğretmen gelişimini önemser. Öğretmenlerine sürekli danışır, fikir alır. Öğretmenin önerine değer verir" (Ö9) demiştir.

Bir yönetici de, "Öğretmenleri mesleki gelişimleri için onları desteklerim.İmkanlar doğrultusunda yapabilecek ne varsa elimden geleni yaparım. Mesleki gelişimin öğretmenlik mesleğinde çok gerekli olduğuna inanırım öğretmenlerimin de bunu yapması için teşvik ederim" (Y2) diyerek görüşlerini belirtmiştir. Tablo 7'de öğretmenlerin okulun geliştirilmesine yönelik çaba göstermelerinin sağlanmasına yönelik tema ve alt temalara ilişkin bilgiler yer almaktadır.

Tablo 7. Öğretmenlerin Okulun Geliştirilmesine Yönelik Çaba Göstermelerinin Sağlanmasına Yönelik Tema ve Alt Temalar

\begin{tabular}{|c|c|c|c|}
\hline \multicolumn{4}{|c|}{ TEMA 5 : Okulun geliş̧irilmesine yönelik çaba göstermelerinin sağlanması } \\
\hline \multirow{11}{*}{ 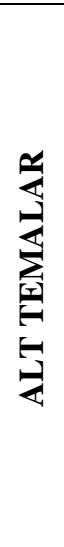 } & \multirow{5}{*}{ 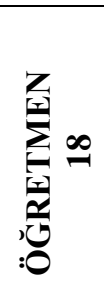 } & Takdir etme & Ö2, Ö4, Ö6, Ö10, Ö13, Ö18 \\
\hline & & Yasal güç kullanma & Ö3, Ö4, Ö5, Ö7, Ö11 \\
\hline & & Okulun parçası olduğunu hissettirme & Ö1, Ö12, Ö14 \\
\hline & & Okul geliştirmenin önemini anlatma & Ö6, Ö10, Ö18 \\
\hline & & Karara katma & Ö15, Ö6, Ö17 \\
\hline & \multirow{6}{*}{ 绨 } & Karara katma & $\mathrm{Y} 1, \mathrm{Y} 10, \mathrm{Y} 18$ \\
\hline & & Takdir etme & Y6, Y7, Y9 \\
\hline & & Okulu benimsetme & Y3, Y7, Y9 \\
\hline & & Kişisel özelliklerine göre etkileme & Y3, Y7, Y9 \\
\hline & & Yasal gücünü kullanma & Y4, Y5 \\
\hline & & Takım çalışmasını vurgulama & Y8 \\
\hline
\end{tabular}

Tablo 7'ye göre, öğretmenlerin okulun geliştirilmesine yönelik çaba göstermelerinin sağlanması için öğretmenlerin çoğu, okul yöneticilerinin takdir etme ve yasal güç kullanma 


\section{Okul Yöneticilerinin Öğretmenleri Etkilemede Kullandıkları Yönetsel Etki Taktikleri}

taktiklerini kullandıklarını belirtmektedir. Okul yöneticilernin çoğu ise, öğrtemenleri okul için çaba göstermelerine yönelik takdir ederek, okulu benimseterek ve kişisel özelliklerine göre etkilediklerini dile getirmektedirler. Bazı öğrtemenler okul yöneticilerinin, okulun bir parçası gibi hissettirdiklerini, okul geliştirmenin öenmi anlattıklarını, karara kattıklarını belirtmektedirler. Yine bazı okul yöneticileri de öğretmenleri etkilemek için yasal güç kullandıklarını, takım çalışmasını vurguladıklarını ifade etmişlerdir.

Okul yöneticilerinin öğretmenlerin okulun geliştirilmesine yönelik çaba göstermelerinin sağlanması için kullandıkları etki taktiği konusunda bir öğretmen; "En başta yasal gücünü kullanır. Daha sonra iletişim kanallarını kullanıyor. Okul için yapılan çalışmaların vicdani boyutu var ancak yapıp karşılık alamadıkça, takdir edilmedikçe yapmamaya başlıyorsun" (Ö5) cümleleriyle görüşünü bildirmiştir. Yine bir yönetici, "İlk olarak okulu benimsemelerini sağlarım. Bunun için öğretmenlerin yaptığı küçük hataları görmezden gelerek onları küstürmem"(Y3) demiştir.

\section{Tartışma ve Sonuç}

$\mathrm{Bu}$ araştırma, okul yöneticilerinin öğretmenleri etkilemede kullandıkları etki taktiklerinin öğretmen ve yönetici görüşlerine göre ortaya konulmasını amaçlamıştır. Araştırmaya göre, okul yöneticilerinin öğretmenleri etkileme alanları beş tema altında toplanmıştır. Bu temalar, öğretmenlerin okulla bütünleşmelerine, başarılarının artırılmasına, görevlerini yerine getirmelerinin sağlanmasına, mesleki gelişimlerinin sağlanmasına ve okulun geliştirilmesine yönelik çaba gösterilmelerinin sağlanmasına yöneliktir. Araştırmanın sonuçlarına göre öğretmenlerin çoğu, okulla bütünleşmelerini sağlamak için okul yöneticilerinin kendilerini okulun bir parçası gibi hissettirmeye çalıştıklarını, kararlara kattıklarını, değer verdiklerini ve yasal güçlerini kullandıklarını belirtmişlerdir. Bazı öğretmenlerde koalisyon kurarak, ödül vererek ve bütünleşmeye yönelik okul kültürü oluşturarak yöneticilerin okulla bütünleşmeleri için kendilerini etkilediklerini dile getirmişlerdir. Okul yöneticilerinin çoğu ise, öğretmenleri okul ile bütünleştirmede yasal güç kullandıklarından daha az bahsetmemektedirler. Okul yöneticilerinin, öğretmenlerin okulla bütünleşmelerinde aile ortamı oluşturma ve iletişim kurma gibi etki taktiklerini kullandıklarını belirtmektedirler. Yine bazı okul yöneticileri bu konuda, öğretmenlerin kişisel özelliklerini gözönünde bulundurduklarını, duygusal iknaya başvurduklarını ve öğretmenlerin isteklerini göz önüne aldıklarını, değer verdiklerini, sosyal programlar düzenlediklerini ve karara kattıklarını ifade etmişlerdir. Anlaşılacağı üzere, öğretmenlerle yöneticilerin etkileme taktikleri konusundaki bazı görüşleri benzerlik taşısa da, yöneticilerin öğretmenlerin aksine yasal güçten bahsetmedikleri görülmektedir. Kabaklı Çimen ve Gezer (2016) tarafından yapılan araştırmada da araştırmayla benzer olarak okul müdürlerinin öğretmenleri etkileme düzeylerinin orta düzeyde olduğu; okul yöneticilerinin uzmanlık ve kişilik özelliklerini kullanarak etkileme özelliklerini geliştirmek için çaba göstermeleri gerektiği sonucuna ulaşılmıştır. Kuru Çetin ve Çınkır da (2014) yaptıkları araştırmalarında, yöneticilerin öğretmenleri etkilemede en çok arkadaşlık, pazarlık, koalisyon yapma ve diretme örgütsel etkileme taktiklerini yüksek düzeyde, yaptırım taktiklerini orta düzeyde ve neden gösterme taktiğini ise düşük düzeyde kullandıklarını bulmuşlardır. Aydın ve Pehlivan (2010) çalışmaları da okul yöneticilerinin görüşleri destekler niteliktedir. Bahsedilen bu araştırmada Aydın ve Pehlivan (2010) müdürlerin çoğunlukla dostluk, koalisyon ve pazarlık stratejilerini kullandıklarını nadiren yaptırım ve girişkenlik stratejilerini kullandıklarını tespit etmişlerdir. Bülbül (2019) tarafından yapılan araştırmaya göre de öğretmen algılarına göre okul yöneticileri en çok akı1 yoluyla ikna etme taktiğini kullandıkları sonucuna ulaşılmıştır.

Yine öğretmenlerin çoğu, başarılarının artırılmasına yönelik okul yöneticilerinin kendilerini etkilemesinde yasal güç ve motive etme taktiklerini kullandıklarını belirtirlerken; okul yöneticilerinin çoğu ise, kullandıkları taktikleri motive etme, mesleki gelişim için yönlendirme ve görev dağılımını uygun yapma şeklinde sıralamaktadırlar. Öğretmenlerin bazıları okul yöneticilerinin başarılarını artırmak için takdir etme, örnek olma karara katma 
başarı için ortam oluşturma ve görevlendirme yapma taktiklerini kullandıklarını dile getirirken; okul yöneticilerinin bazıları görev dağılımını uygun yapma, başarı için uygun ortam oluşturma mesleki değerleri vurgulama rekabet ortamı oluşturma liderlik yapma ve karar katma gibi taktikleri kullandıklarını belirtmektedirler. Bu sonuçlara bakıldığında okul yöneticilerle ögretmenlerin öğretmenleri etkilemede başarı için ortam oluşturma ve karara katma taktikleri konusunda görüşlerinin örtüştüğü anlaşılmaktadır. Özellikle okul yöneticilerinin hem ögretmenlere hem de kendilerinin görüşlerinden istenen şekilde olduğu belirtilebilir. Çünkü okuldaki eğitiminin başarısının anahtarı kaliteli bir okul kültürüne bağlıdır. Okul kültürü, öğretmen üzerinde önemli bir etkiye sahiptir. Okulda yüksek kaliteli olumlu ve profesyonel bir öğretim kültürü olması, öğretmen başarısını da etkilemektedir (Lee \& Li, 2015). Bredeson ve Johnson da (2006) öğretmen öğrenmesi ve gelişimi için destek sağlamanın, model olmanın, koçluk yapmanın, geri bildirim vermenin ve öğretmenlerin yaratıcılıklarını kullanabilecekleri bir eğitim-öğretim ortamı sağlama okul yöneticilerinin görevleri arasında olduğunu ifade etmektedir.

Araştırmada ulaşılan diğer bir sonuçta, öğretmenlerin çoğunun okul yöneticilerinin görevlerini yerini getirmelerini sağlamak için yasal güç kullandıklarını dile getirmeleridir. Yöneticiler ise, öğretmenlerin görevlerini yerine getirmeleri için genellikle sonuçlara vurgu yapma, mesleğin önemini vurgulama ve başarı için ortam oluşturma gibi taktikleri uyguladıklarını belirtmeleridir. Bunun yanında öğretmenler ve yöneticiler, bu temaya yönelik yöneticilerin öğretmenleri etkilemede sonuçlara ve mesleğin önemine vurgu yapma taktiğini kullandıkları konusunda benzer düşünmektedirler. Yine öğretmenler okul yöneticilerinin güven hissettirerek, görevi açıklayarak yöneticilerin kendilerini etkilediklerini; yöneticiler ise ödüllendirme pazarlık yapma ve örnekler gösterme yoluyla öğretmenlerin görevlerini yerine getirmelerini sağladıkları görülmektedir. Ancak öğretmenlerin kendilerini etkilemede yöneticilerin yasal gücü kullandıklarını öğretmenlerin çoğu dile getirirken; okul yöneticilerinden sadece iki yönetici yasal gücü kullandığını dile getirmiştir. Çetin ve Çınkır da (2015; 2018) araştırmalarında öğretmenleri etkilemede samimiyet, pazarlık, koalisyon ve meydan okuma etki taktiklerini yüksek düzeyde kullandıklarını, yasal güç ve yaptırım taktiklerini ise orta düzeyde kullandıklarını tespit etmişlerdir. Yine Aydın ve Pehlivan (2010) ile Kuru Çetin ve Çınkır da (2014) çalışmalarında müdürlerin çoğunlukla okul yöneticilerinin pazarlık stratejilerini kullandıklarını belirlemişlerdir. Doğan ve Çelik'te (2019) okul yöneticilerinin öğretmenleri motive etmek, okul amaçlarına yönelik öğretmenlerin çabalarını arttırmak için ödül gücünü kullanmayı daha çok tercih ettiklerini belirlemişlerdir. Mangaltepe'nin (2012) araştırmasında okul müdürlerinin yönetim becerileri ile öğretmenleri etkileme becerileri ilişkin algılan arasında yüksek düzeyde pozitif yönlü ilişki olduğu saptanmıştır. Yine Koşar ve Çalık (2011), okul yöneticilerinin kullandıkları güç stillerinin okuldaki örgüt kültürü ile ilişkili olduğunu; kişilik ve ödül gücünün etkin olduğu okullarda daha olumlu, yasal ve zorlayıcı gücün etkin olduğu okullarda ise diğerlerine nazaran daha düşük seviyede olumlu bir atmosfer olduğunu belirtmişlerdir.

Araştrmanın bir başka sonucuna göre de hem öğretmenlerin hem de okul yöneticilerinin çoğuna göre öğretmenlerin mesleki gelişimine yönelik kullanılan etkileme taktikleri hizmet içi eğitime yönlendirme ve mesleki gelişimi sağlamadır. Bunun yanında öğretmenler okul yöneticilerinin kendilerini mesleki gelişimlerinin sağlanmasına yönelik olarak koşulları kolaylaştırma, bilimsel etkinlikleri destekleme kararlara katma ve ödül yoluyla desteklediklerini belirtmektedir. Okul yöneticileri ise, öğretmenleri etkilerken mesleki değeri vurgulama sorumluluk aşılama motive etme ve kararlara katma gibi etkileme taktiklerini kullandıklarını ifade etmektedirler. Genel olarak değerlendirildiğinde, hem öğretmenler hem de okul yöneticileri öğretmenlerin mesleki gelişimlerine yönelik okul yöneticilerinin kullandıkları etki taktikleri konusunda yine benzer düşünmektedir. Okul yöneticilerinin öğretmenleri hizmet içi eğitime yönetme bilimsel etkinliklere katılımını sağlama ve mesleki gelişimlere katılabilmeleri için koşulları kolaylaştırma taktiklerini uyguladıkları anlaşılmaktadır. Okul yöneticileri, öğretmenlerin performans standartlarına ulaşmaları ve mesleki gelişimleri için ihtiyaç 


\section{Okul Yöneticilerinin Öğretmenleri Etkilemede Kullandıkları Yönetsel Etki Taktikleri}

duydukları gerekli becerilerin kazanılmasında öğretmenlere yardımcı olacak kaynakları sağlamalı ve öğretmen başarısını geliştirmelidirler (Eller \& Eller, 2016). Öğretmenlerin mesleki becerileriyle ilgili sıkıntıya düştüklerinde onlara destek sağlayacak bir yöneticinin olduğunu bilmeleri onları rahatlatacaktır. Öğretmenlerin eğitim-öğretim konularında tam yetkin bir yönetici algısına sahip oldukları okul ortamları onların mesleki gelişimlerinde önemli bir faktördür( Bredeson \& Johansson, 2006). Bursalığlu'na (2002) göre de etkinin dış yolları yetki, enformasyon ve hizmet içi eğitim; iç etki yolları ise, bireysel gereksinmelerin karşılanması, karar sürecine katılma olanağ 1 ve örgütün üyelere benimsetilmesidir.

Öğretmenlerin okulun geliştirilmesine yönelik çaba göstermelerinin sağlanması için öğretmenlerin çoğu, okul yöneticilerinin takdir etme ve yasal güç etki taktiklerini kulandıklarını düşünmektedirler. Okul yöneticilerinin çoğu ise, öğretmenleri okul için çaba göstermelerine yönelik takdir ederek, okulu benimseterek ve kişisel özelliklerine göre etkileyerek etkilediklerini dile getirmektedirler. Bazı öğretmenler yine okul yöneticilerinin kendilerini okulun bir parçası gibi hissettirdiklerini, okul geliştirmenin önemini anlattıklarını karara kattıklarını belirtmektedirler. Bazı okul yöneticilerinin de öğretmenleri yasal güç kullanarak ve takım çalışmasını vurgulayarak etkilemeye çalıştıklarını belirttikleri görülmektedir. Öğretmen ve yönetici görüşlerinden okul yöneticilerinin öğretmenleri okulun geliştirilmesine yönelik çaba göstermeleri için etkilemede kullandıkları yasal güç dışında, bazı taktiklerin alan yazınla da bağdaştığ 1 görülmektedir. Baldwin ve Grayson (2004) göre de yöneticiler, çalışanların örgütün hedeflerine doğru ilerlemesini sağlamak, çalışanların bireysel hedeflerini desteklemek ve ast üst ilişkilerini geliştirmek gibi stratejileri uygulayarak örgütte arzu edilen sonuçlara ulaşabilmektedirler.

Araştırmadan elde edilen sonuçlara göre şu öneriler ileri sürülebilir.

Öğretmen ve yöneticiler arasında etki taktikleri konusunda algı farkl11ıkları görülmektedir. Bu algı farklılıklarının nedeni araştırılabilir.

Öğretmen görüşlerine göre, okul yöneticilerinin öğretmenleri etkilemede yasal güce başvurdukları anlaşılmaktadır. Özellikle görevlerin yerine getirilmesinin sağlanması ve okul gelişimi için çaba göstermelerinin sağlanması temalarında bazı okul yöneticilerinin etkileme taktiği olarak yasal güce başvurduklarını dile getirdikleri görülmektedir. Çalışanları etkilemede konumdan kaynaklı güçlere başvurulmasının alan yazına göre kişiye bağlı uzmanlık gücüne göre daha etkisiz olacağı göz önünde bulundurulduğunda, okul yöneticilerine verilecek eğitimlerle bu konuda farkındalık sağlanabilir.

Yine araştırma sonuçlarından anlaşılacağı üzere, okul yöneticilerinin öğretmenlerin etkilemede vizyon etrafında bütünleştirme, mesleki gelişimleri için performanslarını yönetme, liderlik yapma, liderliği paylaşma, kurum liderliğini önemseme, mentorlük yapma v.b etki taktiklerini kullanmadıkları görülmüştür. Bu konularda okul yöneticilerine yönelik bilgilendirici ve uygulamalı çalışmalar yapılabilir.

Araştırmada öğretmenlerin okulla bütünleşmelerine, başarılarının artırılmasına, görevlerini yerine getirmelerinin sağlanmasına, mesleki gelişimlerinin sağlanmasına ve okulun geliştirilmesine yönelik çaba gösterilmelerinin sağlanmasına yönelik okul yöneticilerin kullandıkları etki taktikleri belirlenmiştir. Okulun diğer çalışma alanlarına yönelik, okul yöneticilerinin gösterdiği etki taktikleri başka nitel çalışmalarla ortaya konulabilir. 


\section{Kaynaklar}

Akçay, A. (2003). Okul müdürleri öğretmenleri etkileyebiliyor mu? Milli Eğitim Dergisi, 157.www.meb.gv.tr

Aydın, İ. \& Pehlivan, Z. (2010). Strategies and personality types used by primary school principals in Turkey to influence teachers (Ankara case). Procedia Social and Behavioral Sciences, 2, 36523659 .

Aydoğan, İ. (2008) Okul yöneticilerinin öğretmenleri etkileme becerileri. Selçuk Üniversitesi Ahmet Keleşoğlu Eğitim Fakültesi Dergisi,25, 33-51.

Balıı, A.\& Aydın, İ. (2003). Anadolu Öğretmen Liseleri için eğitim yönetimi. İstanbul: Milli Eğitim Basımevi.

Baldwin D.\& Grayson,C.(2004). Positive influence. How leaders get others to see it their way. Leadership in Action, 24(1),8-11.

Balser, D. B. \& Carmin, J. (2009). Leadership succession and the emergence of an organizational identity threat. Nonprofit Management \& Leadership, 20 (2), 185-201.

Barutçugil, İ. (2002). Performans yönetimi. İstanbul: Kariyer Yayınc1lık.

Bredeson, P. V., \& Johannson, O. (2000). The school principal's role in teacher professional development. Journal of In-Service Education, 26(2), 385-401.

Bursalığlu, Z. (2002). Okul yönetiminde yeni yapı ve davranış. Ankara: Pegem A Yayıncılık.

Bülbül, S. (2019).Okul müdürlerinin kullandıkları etkileme taktikleri ile ögretmenlerin işe tutkunluk düzeyleri arasındaki ilişki (Yayımlanmamış Yüksel Lisans Tezi). Uşak Üniversitesi sosyal Bilimler Enstitüsü.

Büyüköztürk, Ş., Çakmak, E. K., Akgün, Ö. E., Karadeniz, Ş. \& Demiral, F. (2012). Bilimsel araştırma yöntemleri.(12.baskı). Ankara: Pegem Akademi.

Cable D. M \& Judge, T.A. (2003) Managers' upward influence tactic strategies: The role of manager personality and supervisor leadership style. Journal of Organizational Behavior, 24, 197-214

Çetin, S. K., \& Çınkır, S. (2015). School administrators' and teachers' opinions about influencing each other. European Journal of Educational Research, 5(4), 181-187.

Çetin, S. K., \& Çınkır, S. (2018). Relation between school managers and teachers downward and upward influence tactis and organizational justice. International Journal of Educational Leadership and Management, 6(2), 126-153.

Dağl1, E., \& Çalık, T. (2016). İlköğretim okullarında müdürlerin kullandıkları etkileme taktiklerinin öğretmenlerin örgütsel vatandaşlık davranışları ve okul farkındalığı ile ilişkisi. Kuram ve Uygulamada Eğitim Yönetimi Dergisi, 22(1), 29-58.

Doğan, H.\& Çelik, K.(2019). Okul yöneticilerinin gücü kullanma stillerinin öğretmenlerin örgütsel bağlllıkları ve iş performansları ile ilişkisi. Eğitim ve Bilim, 44( 198), 37-55.

Duyar,İ., Aydın, İ \& Pehlivan, Z. (2009). Analyzing principal influence tactics from a cross-cultural perspective: Do preferred influence tactics and targeted goals differ by national culture?, in Alexander W. Wiseman (Ed.) Educational Leadership: Global Contexts and International Comparisons, 11, 191 - 220.

Eller, J. F. \& Eller, S. H. (2015). The main of teacher evulation. https://www.naesp.org, İndirilme Tarihi:1.11.2016.

Eroğlu, E. \& İspir, B.(2006) Örgütsel iletişim sürecinde yönetimsel ikna ve etkileme :Örnek olay incelemesi. II.Ulusal Halkla İlişsiler Sempozyumu, 27-28 Nisan 2006, Kocaeli Üniversitesi, Kocaeli 


\section{Okul Yöneticilerinin Öğretmenleri Etkilemede Kullandıkları Yönetsel Etki Taktikleri}

Gözü, C. (2012). Influence tactics and leadership effectiveness in Turkey and USA: Mediating role of subordinate commitment. New York: A Dissertation Submitted To The University At Albany, State University of NewYork.

Hoy, W. K. \& Miskel, C.G. (2010).Eğitim yönetimi. (Çeviri Editörü: Selahattin Turan). Ankara: Nobel Yayıncilik.

Higgins, C. A., Judge, T. A., \& Ferris, G. R. (2003). Influence tactics and work outcomes: A meta analysis. Journal of Organizational Behavior: The International Journal of Industrial, Occupational and Organizational Psychology and Behavior, 24(1), 89-106.

İspir, N. B. (2008). Yöneticilerin kullandı̆̆ etki taktikleri ve kurum kültürü: Uygulama ve yönetimsel etkileme için model önerisi(Yayımlanmamış Doktora Tezi). Anadolu Üniversitesi Sosyal Bilimler Enstitüsü. Eskişehir.

Jiasheng, S. (2011). Leaders' influence tactics: A study of Chinese Employees. 2nd International Conference on Artificial Intelligence, Management Science \& Electronic Commerce (AIMSEC) ,3093-3096.

Kabaklı Çimen, L., \& Gezer, E. (2016). İlkokul müdürlerinin yönetim ve öğretmenleri etkileme becerilerinin öğretmenler tarafından değerlendirilmesi. Journal of Human Sciences, 13(3), 45204544.

Kacmar, K. M., Carlson, D.S. \& Harris, K.J.(2013).Interactive effect of leaders' influence tactics and ethical leadership on work effort and helping behavior.The Journal of Social Psychology, 153(5), 577-597.

Kipnis, D., Schmidt, S., Swaffin-Smith, C., \& Wilkinson, I. (1984). Patterns of managerial influence: shotgun managers, tacticians, and bystanders. Organizational Dynamics, 12(3)58-69.

Kipnis, D. \& Schmidt, S. M. (1988). Upward-influence styles: Relationship with performance evaluations, salary and stress. Administrative Science Quarterly, 33, 528-542.

Koşar, S., \& Çalık, T. (2011). Okul yöneticilerinin yönetimde gücü kullanma stilleri ile örgüt kültürü arasındaki ilişki. Kuram ve Uygulamada Ĕ̆itim Yönetimi [Educational Administration: Theory and Practice], 17(4), 581-603.

Kraft, M. A.,\& Gilmour, A. F. (2016). Can principals promote teacher development as evaluators? A casestudy of principals' views and experiences. Educational Administration Quarterly, 52(5), 711-753.

Kuru Çetin, S. \& Çınkır, Ş.(2014).Okul yöneticileri ve öğretmenlerin birbirlerini etkileme taktiklerinin örgütsel adalet ile ilişkisi. Mehmet Akif Ersoy Üniversitesi Ĕgitim Bilimleri Enstitüsü Dergisi, 3(5), 50-64.

Lee, Y.D.,Chiang, Chen, S.H. \& Chen, P.C. (2010). The moderating effect of employees' personality on the relationship between charismatic leadership and organizational citizenship behavior: analysis of the high-tech firms in Southern Taiwan. Technology Management for Global Economic Growth (PICMET), Proceedings of PICMET '10: https://ieeexplore.ieee.org/document/5602152

Lee, H. H. \& Li, M.F. (2015). Principal leadership and its link to the development of a school's teacher culture and teaching effectiveness: A casestudy of an award-winning teaching team at an elementary school. International Journal of Education Policy \& Leadership, 10(4),1-17.

Maharaj, S. (2014). Administrators' views on teachere valuation: Examining Ontario's teacher performance appraisal. Canadian Journal of Educational Administration and Policy,152, 1-53.

Mangaltepe, E. (2012). Illköğretim okul müdürlerinin yönetim becerileri ile ögretmenleri etkileme becerilerine ilişskin öğretmen görüşleri (Yayınlanmamış Yüksek Lisans Tezi) Abant İzzet Baysal Üniversitesi,Eğitim Bilimleri Enstitüsü, Bolu.

Miles, M. B. \& Huberman, A. M. (1994). Qualitative data analysis. London: Sage. Publications.

Mosca, J. B., Fazzari, A. \& Buzza, J. (2010). Coaching to win: A systematic approach to achieving productivity through coaching. Journal of Business \& Economics Research, 8(5), 115-130.

Uygun, H. (2006). İlköğretim okulu öğretmenlerinin algllarına göre okul müdürleri ile ilköğretim müfettişlerinin ögrretmenleri etkileme Düzeyi(Yayınlanmamış Yüksek Lisans Tezi). Dokuz Eylül Üniversitesi, Eğitim Bilimleri Enstitüsü. İzmir. 
Ünal A. \& Özaslan, G. (2017). Okul yöneticilerinin maarif müfettişlerine yönelik etkileme taktikleri. Mersin Üniversitesi Eğitim Fakültesi Dergisi, 13(1), 176-195.

Yıldırım, A. ve Simsek, H. (2005). Sosyal bilimlerde nitel araştırma yöntemleri (5. Baskı). Ankara: Seçkin Yayıncılık.

Yukl, G. A. (2013) Leadership in organizations ( 8th ed.) Includes bibliographical references and index https://businessksu.files.wordpress.com./2017/02/leadership_in_organizations 
Okul Yöneticilerinin Öğretmenleri Etkilemede Kullandıkları Yönetsel Etki Taktikleri

Extended Abstract

\section{Introduction}

Employees in an organization have the most important role to reach the aim of the organization. For this reason, the exposure of the organization employees by organizational goals have a critical importance for organizational success (Balser \& Carmin, 2009; Mosca, Fazzari \& Buzza, 2010; Lee, Chiang, Chen \& Chen, 2010). For the success of the school, school administrators should use the influence tactics for motivating teachers, gathering them around organizational goals, changing teachers' attitudes and behaviors for the organizational purpose, assuring themselves to school, and most importantly, in developing the education process (Akçay, 2003; Duyar, Aydın \& Pehlivan, 2009). In this study, it is tried to determine the Influence tactics of school administrators on influencing teachers in addition to the tactics known in the literature. For this reason, this study tries to determine which tactics are used by school administrators in terms of teachers' and administrators' views. For this purpose, the following questions were searched.

What are the tactics of school administrators for teachers' school integration, the fulfillment of their duties and their professional development according to the teacher's views?

What are the tactics of school administrators about the teachers' integration into the school, the fulfillment of their duties and their professional development according to the school administrators?

\section{Method}

Qualitative research method was used in the research. The research with phenomenological design tried to determine the tactics of school administrators according to the opinions of teachers. While determining the study group volunteering is taken as a base of it. Qualitative research method was used in the research. The study group consists of 18 teachers and 10 school administrators working in Uşak. Inputs have been collected by semi-structured interview technique using voice recording method. Thus, data loss is prevented. When the data has reached the saturation point, the data collection has been terminated. Content analysis technique has been used in data analysis. For the analysis of the data, first the interviews were transferred to the computer environment, and themes and sub-themes were created due to the focus on the most recent words. One-to-one interviews were given from the interviews conducted to reveal the findings for the theme. These transfers were transferred to the teachers in the analysis of the data by the codes of Ö1...Ö18 for the administrators Y1...Y10.

\section{Result and Discussion}

According to the results of the study; most of the teachers stated that school administrators tried to make them feel like part of the school they added to the decisions, they valued and used their legal powers in order to ensure their integration with the school. Some of the teachers, expressed that they have been influenced for school integration by establishing a coalition, awarding and creating a school culture for integration. Most school administrators do not mention that they use legal power to integrate teachers into the school and state that teachers use influence tactics such as creating a family environment and communicating in school integration. Again some school administrators stated that they take into consideration the personal characteristics of the teachers, applied to emotional persuasion and they take into account the wishes of the students, value them, organize social programs and make decisions. However most of the teachers state that school administrators use tactics of legal power and motivation to influence themselves in order to increase their success; Most of the school administrators sort the tactics they use as, motivation directing them for professional development and making the appropriate task distribution. Some of the teachers expressed the school administrators use the tactics of appreciation, exemplifying, creating an environment for 
success, involving them to the decisions and giving responsibility in order to increase their success; Some of the school administrators say that they use tactics such as leadership and decision-making to create a competitive environment, emphasizing professional values, making the appropriate distribution of tasks, and creating an appropriate environment for success. Another result of the research is that teachers use legal power to enable school administrators to fulfill their duties; administrators often use the tactics such as emphasize the results, emphasize the importance of the profession and create an environment for success.

In addition the influence of administrators on teachers, emphasizing the results and emphasizing the importance of the profession. They think similar. Again, teachers say the school administrators influence them by giving confidence and explaining the task whereas it is seen that the administrators influence the teachers by rewarding bargaining and showing examples to fulfill their duties. However, most of the teachers state that the school administrators use legal power in influencing them, only two school administrators accept that they use the legal force. According to another result of the research, both the teachers and the school administrators' influence tactics are used to provide and support the development and professional development of in-service training. In addition, the teachers state that school administrators support themselves for the professional development, by facilitating the conditions, encouraging scientific activities and making decisions.

School administrators say that they use tactics such as emphasizing professional value, giving responsibility, motivating and involving them to the decisions to influence teachers. In general both teachers and school administrators think similar about the influence tactics used by school administrators for the professional development of teachers. It is understood that school administrators implement the tactics of facilitating teachers' participation in in-service training and facilitating the conditions for participation in professional development. Most teachers think that school administrators use appreciation and legal power tactics in order to ensure that teachers make efforts to develop the school. Most school administrators say that they appreciate teachers for their efforts for the school, and they influence them by adopting to school and according to personal characteristics. Some teachers also state that the school administrators make them feel like part of the school and that they explain the importance of school development. Some school administrators also stated that they use legal force and emphasize team work to influence teachers. According to the results of the research, the following suggestions can be asserted:

There are differences in perception of influence tactics between teachers and administrators. The reason for these differences should be investigated It is understood that the administrators use legal power more as an influence tactic towards teachers. Considering the fact that resorting to position-based power as the power of influencing employees will be more ineffective than the expertise and charismatic power, awareness may be provided to school administrators through the trainings to be given for the success of schools. As can be understood from the results of the research, it is seen that school administrators, do not use the influence tactics that are; integrate around vision, develop their profession and manage their performance act as a leader, share leadership, emphasize on organizational leadership and mentoring. Informative studies can be conducted on these issues for school administrators. 